\title{
LITERACKIE I PLASTYCZNE OBRAZY ŚMIERCI W ILUSTROWANYCH WYDANIACH POLSKIEJ XIX-WIECZNEJ BELETRYSTYKI
}

Do zilustrowania omawianych w artykule tez wybrałam cztery obrazy śmierci zaczerpnięte z polskiej literatury XIX wieku oraz towarzyszące im przedstawienia graficzne. Sceny te w wymiarze plastycznym i tekstowym ukazują zarówno makabrę, jak i wzniosłość śmierci. Przedmiotem mojego zainteresowania są przede wszystkim interferencje zachodzące pomiędzy tekstem a towarzyszącymi mu ilustracjami. W sposób szczególny zajmuje mnie więź pomiędzy sztukami plastycznymi aliteraturą. Rozmaite jej formy można obserwować w przestrzeni książki ilustrowanej. W obszarze badawczym znajdą się również: sztuka ilustracji wobec wyzwania czasu oraz respektowanie lub przekraczanie przez grafików konwencji estetycznych epoki (tu jedną zkluczowych będzie kategoria okrucieństwa). Poruszam także zagadnienia pomocnicze, takie jak: kształtowanie wyobrażeń zbiorowych poprzez wizję ilustratora, plastyczne eksponowanie wybranych treści utworu, znaczenie ilustracji jako integralnego elementu edytorskiego opracowania. Wszystkie te kwestie łączy współdziałanie słowa i obrazu, tworzące wspólną przestrzeń spotkania wyobraźni literackiej i plastycznej.

Analizy ilustracji jako sposobu operowania na tekście dokonuję w ujęciu interdyscyplinarnym. Zagadnienia, które omawiam, spotykają się na pograniczu dwóch głównych dyscyplin: historii literatury i historii sztuki, a także bibliologii oraz historii kultury, w tym zwłaszcza polskiej kultury wydawniczej XIX wieku.

Na początku wyjaśnijmy, jaką rolę wyznaczano ilustracji w omawianym okresie. Jak wskazuje Karol Głombiowski, niemal do końca tego stulecia

ilustracja starała się z werystyczną dokładnością opisywać treść dzieła, konkretyzować w utworze literackim w sposób naturalistyczny to, co przez poetę czy powieściopisarza nie zostało do końca, dokładnie, we wszystkich szczegółach przedstawione ${ }^{2}$.

\footnotetext{
${ }^{1}$ Dąbrówka Mirońska — doktorantka w Instytucie Polonistyki Stosowanej na Wydziale Polonistyki Uniwersytetu Warszawskiego. Od 2006 roku związana z polskim rynkiem wydawniczym zarówno książkowym, jak i prasowym. Obecnie redaktor prowadzący i wydawca w Wydawnictwie Naukowym PWN. W swoim dorobku ma m.in. publikacje w magazynach: „Humanistyka XXI wieku. Rocznik Doktorantów Wydziału Polonistyki Uniwersytetu Warszawskiego” oraz „Balkan United”.

${ }^{2}$ K. Głombiowski, Ksiażka w procesie komunikacji społecznej, Wrocław 1980, s. 58. Por. także E. Skierkowska, Wspótczesna ilustracja książki, Wrocław 1969, s. 13.
} 
Warto zauważyć, że jeszcze pod koniec lat sześćdziesiątych XX wieku badacz przedstawiał tezy, które znamy z tekstów XIX-wiecznych krytyków. Nawet jeżeli opowiadali się oni za nadaniem ilustracji rangi samodzielnej wypowiedzi artystycznej, w ich rozumieniu zadaniem tej gałęzi sztuki było dosłowne i konkretne odtworzenie warstwy wyglądów oraz przedmiotów przedstawionych w utworze literackim. Karol Głombiowski dodatkowo podkreśla:

nie ma żadnej wątpliwości, co do tego, że ilustrator dzieła literackiego winien podporządkować się treści utworu i że ilustracja winna być inspirowana przez autorskie słowo. Rycina postępuje za tekstem, a nie może tekstu zdominować ani zająć w książce miejsce niezależne, poddana jedynie rygorom własnej sztuki. Inaczej bowiem — kłócąc się z wyobrażeniami sugerowanymi przez tekst — ilustracja może tylko zaszkodzić estetycznemu przeżywaniu utworu³.

Jak wspomniałam, również w powszechnym odbiorze ówczesnej krytyki ilustracja nie była aktem twórczym, a jedynie unaocznieniem, „uzmysłowieniem” cudzych myśli, dosłownym i konkretnym odtworzeniem warstwy wyglądów oraz przedmiotów przedstawionych w utworze literackim. W to wierzyli również odbiorcy, a przynajmniej nie docierają do nas głosy świadczące o tym, że ktokolwiek myślał inaczej.

W istocie prawda na temat relacji pomiędzy tekstem a ilustracją była znacznie bardziej złożona, wykraczając poza stosunek czysto naśladowczy. Postaram się pokazać, jak ilustracja stawała się lekturą tekstu, operacją na słowie, w jaki sposób rysownicy dopuszczali się transformacji, przekształceń prezentowanych sensów, a nawet zafałszowań wobec literackiego pierwowzoru. Przede wszystkim zaś — jak wprowadzali aspekt ideologiczny do proponowanych przez siebie wizualizacji.

Przejdźmy zatem do przykładów, z których pierwszym będzie scena opłakiwania tytułowej bohaterki opisana przez Antoniego Malczewskiego w poemacie Maria. Poeta zapisał się w historii polskiej literatury jako autor jednej książki, która za jego życia nie przyniosła mu ani rozgłosu, ani pieniędzy ${ }^{4}$. Wydana po raz pierwszy w 1825 roku Maria. Powieść ukraińskas, początkowo niedoceniana, z czasem stała się jedną

${ }^{3}$ K. Głombiowski, dz. cyt., s. 60. Zob. także: S. Szuman, Ilustracja $w$ ksiązkach dla dzieci i młodzieży, Kraków 1951, s. 15-23. M. Porębski, Ikonosfera, Warszawa 1972, s. 195.

${ }^{4}$ To zadziwiające, że o życiu autora Marii wiemy tak niewiele. Antoni Malczewski to postać, która zostawiła po sobie legendę do dziś budzącą niepokój i liczne wątpliwości. Uczeń Gimnazjum Wołyńskiego i chluba tej szkoły, podporucznik korpusu inżynierów w Szkole Aplikacyjnej Artylerii i Inżynierów w Warszawie, adiutant polowy przy generale Ksawerym Kosseckim, obrońca Modlina, więzień w niewoli rosyjskiej, porucznik w sztabie kwatermistrzostwa generalnego wojsk Królestwa Polskiego. Światowiec, podróżnik, ósmy na świecie zdobywca Mont Blanc i pierwszy, który wspiął się na alpejski szczyt Aiguille du Midi. Mężczyzna uwikłany w burzliwy romans z żoną swojego przyjaciela, nerwowo chorą Zofią z Modzelewskich Rucińską. Wreszcie człowiek chory, rozczarowany, opuszczony przez bliskich i przyjaciół, borykający się z ciężką sytuacją materialną i trudnym położeniem życiowym. Umarł w nędzy i samotności 2 maja 1826 roku, na kilka dni przed swoimi trzydziestymi trzecimi urodzinami.

${ }^{5}$ Pierwodruk: A. Malczewski, Maria. Powieść ukrainska, Warszawa 1825. Ta pierwsza edycja Marii była niezwykle skromna. Nie posiadała zadrukowanej okładki - stanowił ją szaroniebieski cienki papier. Przyczyn ubogiej formy edytorskiej pierwszego wydania należy upatrywać w ograniczonym budżecie autora, który w tym przypadku był jednocześnie „nakładcą”. Co ciekawe, w kontekście późniejszej popularności Marii, pierwodruk tej „powieści ukraińskiej” pozostał w zasadzie niedostrzeżony przez warszawską krytykę. 
z ulubionych lektur polskich czytelników, o czym świadczy imponująca liczba wydań zarówno ilustrowanych, jak i nieilustrowanych. Od początku lat trzydziestych XIX wieku aż do końca lat czterdziestych XX wieku Maria miała przeszło pięćdziesiąt edycji. „Niezwykła była poczytność tego romantycznego poematu, „powieści ukraińskiej«, tła dla wielu już ilustracji [...]"6, jak podkreśla badaczka Janina Wiercińska, autorka opracowania monograficznego na temat Michała Elwiro Andriollego, jednego z ilustratorów Marii. Poemat cieszył się olbrzymią popularnością, doprowadzoną wręcz do stanu niezdrowego przesytu, tak jak to odczuwał Józef Ignacy Kraszewski i czemu dał publicznie wyraz u progu lat siedemdziesiątych dziewiętnastego wieku ${ }^{7}$. Utwór Malczewskiego cieszył się zainteresowaniem nie tylko wśród czytelników, inspirował także wyobraźnię artystów i stał się dla wielu grafików impulsem do podjęcia dzieła zilustrowania go. Wśród tych, którzy podjęli próbę skonkretyzowania w plastycznej formie wybranych scen poematu, byli tak cenieni twórcy, jak wspomniany Michał Elwiro Andriolli, Wojciech Gerson czy Antoni Zaleski.

$\mathrm{Na}$ marginesie możemy stwierdzić, że kanonicznymi przedstawieniami sceny opłakiwania przy łożu śmierci są w polskim malarstwie dwa obrazy: motyw ten znajdujemy na płótnie Jacka Malczewskiego Śmierć Ellenai (inny tytuł to Na tożu śmierci, 1907) oraz w słynnym przedstawieniu malarskim Józefa Simmlera Śmierć Barbary Radziwittówny (1860). Poemat Malczewskiego w oczywisty sposób prowokował wyobraźnię twórców ilustracji do tego, żeby ten temat zainicjować. Przypomnijmy, akcja powieści poetyckiej rozgrywa się na Ukrainie w wieku XVII. Powracający z bitwy Wacław odnajduje swą nieżywą żonę, utopioną na polecenie jego ojca, Wojewody. Uważa się, że dzieje Marii i Wacława stanowią transpozycję autentycznych losów Gertrudy Komorowskiej, pierwszej żony Szczęsnego Potockiego. Przeciwny małżeństwu ojciec pana młodego, wojewoda wołyński Franciszek Salezy Potocki, polecił zamordować synową, czego dokonano 13 lutego 1771 roku.

Oto jak scenę odnalezienia nieżywej Marii opisał Malczewski:

Na nierozsłanym łożu, w żałobnej odzieży

Rozciągnięta niewiasta uśpiona tam leży;

Ale jej snu twardego Wygoda nie pieści;

I jakby nagłą przerwą gwałtownych boleści,

Jeszcze w jej sinej twarzy cierpienie zostało,

\footnotetext{
${ }^{6}$ Andriolli. Świadek swoich czasów. Listy i wspomnienia, oprac. J. Wiercińska, red. nauk. W. Jaworska, Wrocław-Warszawa-Kraków-Gdańsk 1976, s. 36.

${ }^{7}$ Zob. Bolesławita [Józef Ignacy Kraszewski], Omnibus, nakładem Józefa Ignacego Kraszewskiego, Poznań $1869 \mathrm{nr}$ 4, s. 177-179. W tym kontekście ważne są zwłaszcza słowa: „Ilustrowano Marię nie wiem już razy wiele, Zaleski, Fredro a w pojedynczych obrazach, Simmler i mnóstwo artystów; przedmiot to tak zużyty, iż potrzeba było bardzo świeżego i energicznego talentu, aby go odmłodzić i uczynić zajmującym”. Zob. także W. Okoń, Sztuki siostrzane. Malarstwo a literatura w Polsce w drugiej połowie XIX wieku, Wrocław 1992, s. 30: „Pod koniec lat sześćdziesiątych nikt nie musiał już zachęcać malarzy do sięgania do popularnych tekstów literackich, a liczba powstających "przyliterackich" obrazów była tak duża, że niektórzy krytycy zaczęli wręcz ubolewać nad nadmierną eksploatacją niektórych utworów, takich jak np. Maria A. Malczewskiego".
} 
Choć spokojne, bez ruchu, wyprężone ciało;

I długie jej warkocze spadały w nieładzie,

Nie w takim, w jaki Miłość śpiące wdzięki kładzie;

I smutnie się nadęła wysileniem tłusta,

Jak by się skarżyć chciała, tylko że jej usta

Ścięte silniejszą władzą; a promień księżyca,

Co tę posępną postać migając oświéca,

Tak dziką tkliwość rzucał w przymrużone oczy,

$\mathrm{Z}$ jaką wizg upiorzycy, gdy kochanka zoczy.

To młoda śliczna Maria - rycerz przed nią stoi -

Przyniósł jej ziemskie szczęście — i czegoż się boi?

To młoda śliczna Maria? oh! Jakże zmieniona!

Czy już się będzie robak tulić do jej łona?

$[\ldots]$

Lecz gdy silne rycerza unosi ją ramię,

W jakież okropne ruchy jej kibić się łamie!

Nie z tą giętką lotnością, co w dół je przyciska,

Lecz w całym opuszczeniu świeżego zwaliska,

Zwieszone ręce, głowa, zdrętwiałe już nogi

Czynią z niej przedmiot straszny, jemu jeszcze drogi ${ }^{8}$.

Przyjrzyjmy się postaci głównej bohaterki, tak jak ją zobrazowali graficy. Pomimo że poszczególne przedstawienia plastyczne różnią się pod względem dynamizmu i nacechowania patosem, wszystkie łączy silna estetyzacja postaci nieżywej Marii, a zatem uniknięcie tego, co sugestywnie pokazał sam poeta: ciała, które nie tylko jest nieżywe, ale — jak pisze Malczewski — zmienione pod wpływem gwałtownej śmierci. Twarz ślicznej niegdyś Marii jest „wysileniem tłusta”, a zaszłe zmiany budzą makabryczne skojarzenia z przyszłym rozkładem („Czy już się będzie robak tulić do jej łona?”). W efekcie piękna dziewczyna stała się „przedmiotem strasznym”, w plastycznych wizjach wygląda natomiast tak, jakby spała. Na ilustracjach wydarzyło się miraculum mortuorum, dzięki któremu Wacław ujrzał niezmienione rysy ukochanej. Wszystko to, co w tekście jest makabryczne, na ilustracjach staje się namiętne, moralne i żałobne. Tak wygląda „piękna śmierć XIX wieku” (ilustr. 1).

Artyści nie ukazali szpetoty i ohydy zwłok, przed czym nie cofnął się przecież Malczewski w opisie literackim. Pisarz skoncentrował się na okropności śmierci, ilustratorzy — na buncie romantycznego kochanka, co z kolei najlepiej przedstawiają ilustracje Andriollego ${ }^{10}$ i Gersona $^{11}$ (ilustr. 2, 3, 4).

U tego ostatniego ciało Marii znamionuje bezwładność kukły, warto natomiast zwrócić uwagę na to, że główną postacią kompozycji jest Wacław, wykonujący pate-

\footnotetext{
${ }^{8}$ A. Malczewski, Maria. Powieść ukrainska, Kraków 2002, s. 47-48.

${ }^{9}$ P. Ariés, Człowiek i śmierć, Kraków 1989, s. 434.

${ }^{10}$ A. Malczewski, Maria. Powieść ukraińska, wyd. 1 z ilustracjami M. E. Andriollego, Warszawa 1876. Fotodruki według rysunków M. E. Andriollego.

${ }^{11}$ A. Malczewski, Maria. Powieść ukraińska, Lipsk-Warszawa 1883. Drzeworyt, rys. W. Gerson, ryt. J. Styfi i in.
} 
tyczny gest protestu. To na nim w pierwszej kolejności spoczywa spojrzenie patrzącego. W tym miejscu należałoby wprowadzić kategorię narracyjności sformułowaną przez Waldemara Okonia. Twierdzi on, że nigdy nie patrzymy na obraz w ten sposób, żeby ogarniać wzrokiem jego całość. Istnieje taki punkt, od którego zaczynamy czytanie dzieła plastycznego, a który staje się dla widza dominantą obrazu — zwłaszcza tak zwanego obrazu o temacie literackim:

pomimo dążenia do jednoczesnego oglądu całego dzieła oraz braku linearnej kierunkowości jego struktury, percepcja jest procesem odbywającym się w czasie, a w przypadku dzieł o skomplikowanej historii zakodowanej w danym przedstawieniu bądź też w ciągu obrazów — czas ten może być znaczny ${ }^{12}$.

To artysta wyznacza zatem kolejność patrzenia na obraz. W przypadku ryciny przedstawiającej Wacława, który dźwiga ciało martwej żony, uwaga widza skupia się w pierwszej chwili na zrozpaczonym mężczyźnie, następnie wzrok wędruje ku temu, co Wacław trzyma w ręku: Marii, której kibić, jak u Malczewskiego, dosłownie łamie się „w okropne ruchy”.

Co ciekawe, ilustratorzy — poza Gersonem i Andriollim — unikali pokazania kontaktu kochanka z ciałem zmarłej, co przecież wyraźnie opisuje cytowany już tekst: „Znowu ją pieści - cuci — z miłością stroskaną / Co by się pocieszyła choć westchnień zamianą". Na sześć plastycznych przedstawień tylko dwa pokazują próbę wejścia w fizyczną bliskość z nieżywą Marią. W pozostałych przypadkach Wacław jest wyraźnie zdystansowany. W swoim rysunku wspaniale uchwycił ten moment Andriolli, ukazując wahanie Wacława, który odruchowo wyciąga rękę do ukochanej, drugą kładzie na jej nadgarstku, jednak w tym geście jest tyle niepewności i wahania, że mamy wrażenie, jakby Wacław miał za moment cofnąć dłoń i wybiec z komnaty — co istotnie czyni w tekście.

Ukazanie zmian fizjologicznych, które zaszły w ciele Marii, bezwładnym i napuchniętym, było nie do przyjęcia dla żadnego z grafików, dlatego postanowili zneutralizować makabrę śmierci, zasłonić ją za pomocą przemyślanych praktyk, między innymi poprzez sztuczną estetyzację wbrew naturze tego rodzaju śmierci. Zamiast realistycznej dosłowności woleli odwołanie się do kategorii wzniosłości. Również czytelnicy niezmiennie oczekiwali wizji anielskiej Marii, której uroda pozostaje nienaruszona nawet po tragicznej śmierci. Rysunki podkreślają zatem piękno i subtelność bohaterki, łagodząc jednoznaczną wymowę tekstu i sprawiając, że czytelnik zbliża się do bohaterów poematu i głębiej wchodzi w ich świat ${ }^{13}$ (ilustr. 5).

${ }_{12}$ W. Okoń, Narracja werbalna a narracja wizualna. Problemy badawcze, [w:] Literatura a malarstwo — malarstwo a literatura. Panorama myśli polskiej XX wieku, red. G. Królikiewicz, Kraków 2009, s. 586.

${ }^{13} \mathrm{~W}$ tym kontekście ciekawą uwagę poczyniła M. Możdżyńska-Nawotka, odwołując się do kwestii wierności historycznej, przejawiającej się w kostiumie. Zestawia ona dwa ujęcia tej samej sceny, a więc obraz Józefa Simmlera, który niewątpliwie stał się sukcesem polskiego XIX-wiecznego malarstwa, oraz namalowany w 1860 roku obraz Józefa Grottgera Zygmunt i Barbara. Autorka zwraca uwagę na przemyślany zabieg kostiumologiczny: „Malarz wykorzystał kostiumy dla osiągnięcia podwójnego celu: zasugerowania konkretnej epoki oraz określenia charakteru postaci i ich wzajemnych relacji w sposób atrakcyjny i czytel- 
Elementy makabry, które uobecniają się w tekście literackim, w ilustracjach zostają zatarte przez patos, co pozwoliło artystom przedstawić śmierć w jej dostojeństwie, zgodnie z XIX-wieczną konwencją malarską. Warto w tym miejscu zwrócić uwagę na zróżnicowanie wizerunków Wacława. Detale jego wojennego rynsztunku nigdy nie są takie same, podobnie zresztą jak alkierz Marii. W książce Poeci wspótcześni przed obrazami wielkich mistrzów Anna Pilch pisze o niezliczonych możliwościach aktualizacji danego tekstu, przejawiających się w jego plastycznych realizacjach. „Żaden tekst nie ma swojego właściwego obrazu, podobnie jak żaden obraz nie ma swojego właściwego tekstu" ${ }^{\prime 4}$ — wydaje się, że to właśnie w odniesieniu do wielości ilustrowanych wydań Marii, tekstu odznaczającego się niebywałą wprost siłą prowokowania wyobraźni, słowa te nabierają szczególnego znaczenia. Historia ilustrowanych wydań Marii pokazuje bowiem dobitnie, że wbrew przekonaniom XIX-wiecznej, a także późniejszej krytyki, sztuka przekładania z języka literatury na język plastyki nigdy nie jest wyczerpana, a żadna graficzna interpretacja tekstu nie może być ostateczna.

Przejdźmy teraz do przykładu innej sceny śmierci. Tym razem wzniosłemu opisowi towarzyszy równie patetyczna ilustracja. Chodzi o śmierć Longina Podpięty z powieści Ogniem i mieczem Henryka Sienkiewicza zilustrowaną przez Juliusza Kossaka ${ }^{15}$ (ilustr. 6).

ny dla widza. Zadanie zakomunikowania kontekstu historycznego spełnia strój króla Zygmunta Augusta, zawierający odtworzone z dużą wiernością elementy kojarzone z wizerunkiem renesansowego mężczyzny (krótkie bufiaste spodnie, obcisłe nogawice, szeroka w ramionach, krótka szata wierzchnia z dekoracyjnie rozcinanymi rękawami, płytkie obuwie o szerokich noskach). W odniesieniu do kostiumu Barbary kwestia wierności historycznej staje się drugorzędna, a jego podstawową funkcją jest wzmocnienie emocjonalnej wymowy sceny. Na obrazach z epoki kobiety spoczywające w łożu ubrane są w mało seksowne długie giezło z rękawami zebranymi w ciasny mankiet i zawicie lub czepek szczelnie zasłaniające włosy. Barbara natomiast została przedstawiona w bieliźnie przywołującej zmysłową atmosferę (neo)rokokowego buduaru: na koszulę bez rękawów narzucony jest ozdobny kaftanik, a jego szeroki rękaw, otwarty wzdłuż wewnętrznego szwu i spięty ozdobnymi kokardami, obnaża białe ramię zwisające bezwładnie we wzruszającym geście. Spod koronkowego czepka spływają długie, rozpuszczone włosy. Strój Barbary podkreśla zatem jej urodę, bezbronność i delikatność zgodnie z kanonami piękna współczesnymi widzowi, czyniąc przez to żal króla po jej stracie bardziej zrozumiałym”. Dalej autorka pisze o „zasadnej krytyce”, z jaką musiał zmierzyć się obraz Grottgera, w najmniejszych szczegółach przedstawiający rzeczywistość bohaterów w myśl postulatu historycznej wierności ubiorów przedstawianych w dziełach sztuki. Jego sposób przedstawienia kostiumów okazał się nieadekwatny do treści psychologicznej: „wydaje mi się — pisze Jan Bołz Antoniewicz w monografii artysty — strona psychiczna nie wystarczająca, a cały aparat kostiumowy, wraz z owym kołpakiem, z drogocennymi sobolami, zarzuconymi przez plecy, ze stanikiem o wolno przypiętych pasach, i z tymi krezami, sztywnemi jak blacha - drobiazgowością swą tylko razi. Czuć, że królowi i królewskiej kochance w tych kostiumach nieswojsko. — Całość przypomina trochę »żywy obraz" wświeżo uszytych kostiumach, frenetycznie oklaskiwany na przedstawieniu dobroczynnym. Te wszystkie smaczki kolorystyczne, lśniące jedwabie, spencer Zygmunta, mieniący się niebieskimi i żółtymi barwami z kanarowo-źłłtymi rękawami, suknia Barbary barwy miedzianej i biały jej stanik z szerokimi, ciemnymi wstęgami, te i wszystkie inne drugorzędne szczegóły wybijają się tu na pierwszy plan i odwracają uwagę od momentu psychologicznego" (zob.: M. Możdżyńska-Nawotka, Od zmierzchu do świtu. Historia mody balowej, Wrocław 2007, s. 188-190).

${ }^{14}$ A. Pilch, Formy wyobraźni. Poeci wspótcześni przed obrazami wielkich mistrzów, Kraków 2002, s. 42.

${ }^{15}$ Album do powieści Henryka Sienkiewicza „Ogniem i mieczem”, Warszawa 1884. Cynk, rys. J. Kossak. 
Scena ta stanowi w polskiej literaturze doskonałą realizację tematu ars bene moriendi - jest to chwalebna śmierć wojownika, rycerza „bez skazy i trwogi”, który poświęca życie dla ojczyzny i wiary. W plastycznym przedstawieniu skumulowano wydarzenia, które w tekście następują sekwencyjnie. Początkowo bowiem Longin jest porównany do odyńca, który rozdziera Tatarów niczym zajadłe kundle. Jego nadludzka siła zdaje się wzrastać z każdą chwilą, a tego, kto odważy zbliżyć się na długość jego miecza, czeka niechybna śmierć. Jednak, gdy tatarska orda spędza Kozaków i Podbipięta widzi skierowane na siebie łuki i strzały wysypywane z kołczanów, zdaje sobie sprawę, że dalszy opór jest bezsensowny. Składa broń i oddaje się modlitwie. Wówczas pada pierwsza strzała, która przeciera mu skroń. Druga po chwili utkwi w ramieniu rycerza.

I gdy pan Longinus powiedział: „Gwiazdo zaranna!” — już strzały tkwiły mu w ramionach, w boku, w nogach... Krew ze skroni zalewała mu oczy i widział już — jak przez mgłę — łąkę, Tatarów, nie słyszał już świstu strzał. Czuł, że słabnie, że nogi chwieją się pod nim, głowa opada mu na piersi... na koniec ukląkł. Potem, na wpół już z jękiem, powiedział pan Longinus: „Królowo Anielska!” — i to były jego ostatnie słowa na ziemi. Aniołowie niebiescy wzięli jego duszę i położyli ją jako perłę jasną u nóg „Królowej Anielskiej”16.

Rysunek Kossaka stanowi zatem przykład tego, w jaki sposób malarstwo radzi sobie $\mathrm{z}$ kategorią czasu. Ilustracja ukazuje moment heroicznej walki, tymczasem strzały już tkwią $\mathrm{w}$ ciele rycerza, co jest sprzeczne z kolejnością wydarzeń przedstawionych w tekście. Sienkiewicz bowiem wyraźnie rozgraniczył moment, kiedy bohater z wojownika staje się męczennikiem. Podbipięta przechodzi metamorfozę: walczy za ojczyznę, ale ostatecznie porzuca broń i umiera za wiarę. Ze słowami modlitwy oddaje i poleca Bogu swoją duszę. Ta patetyczna chwila przypomina śmierć innego męczennika - Świętego Sebastiana przywiązanego do słupa i przeszytego strzałami. Ilustrator zdecydował się przedstawić Longina jako rycerza, jeszcze nie męczennika, jednak śmiertelne strzały, które już zostały wypuszczone, sugerują dalsze rozgrywanie się sceny w czasie.

W tym kontekście warto przywołać dwa inne przedstawienia plastyczne autorstwa Juliusza Kossaka, ilustrujące chwalebną śmierć wojowników na polu bitwy. Pierwszy z nich to ilustracja wyobrażająca śmierć Mohorta ${ }^{17}$, stuletniego starca, który poświęciwszy swe długie życie walce za kraj, umiera jako bohater (ilustr. 7).

Druga $\mathrm{z}$ omawianych ilustracji przedstawia scenę domniemanej śmierci Tadeusza Kościuszki. Kajetan Suffczyński w swoich „obrazach historycznych” Zawsze oni przedstawił ją w ten sposób:

Kościuszkę wszyscy mieli za zabitego, a Ferson chcąc się o tym dokładnie przekonać, wysłał ze sztabu swego majora Tołstoja na odszukanie go; ten wziął z sobą porucznika Drzewieckiego i z nim się udał na pobojowisko. Wiedziano, że Kościuszko z prawego na lewe udał się skrzydło, ale do niego nie dojechał, w tym więc kierunku udał się Tołstoj z Drzewieckim. - Starannie przeglądali oni ciała poległych i dojechali do Onego błota, na którym leżał Kościuszko; w odartym i zbryzganym krwią i błotem ciele nie

\footnotetext{
${ }^{16}$ H. Sienkiewicz, Ogniem i mieczem, t. 2, red. J. Krzyżanowski, Warszawa 1966, s. 343.

${ }_{17}^{17}$ W. Pol, Mohort. Rapsod rycerski z podania, Lwów 1883. Drzeworyt, rys. J. Kossak, ryt. Z. Szymański i A. Zajkowski.
} 
poznał wodza Drzewiecki, ale żołnierz jakiś z pułku Mirowskich w niewolę wzięty, prowadzony tamtędy spojrzał na leżącego i boleśnie zawołał: „Naczelniku mój, ty nie żyjesz!” odwrócił się skwapliwie na te wyrazy Drzewiecki, zeskoczył z konia a wpatrzywszy się lepiej i on poznał Kościuszkę, a przyłożywszy rękę do serca „żyje! żyje!” wykrzyknął radośnie. — Na tę wieść Tołstoj i eskorta jego pospieszyli z pomocą, a kiedy go wzięli na ręce, ranny dał znak życia ${ }^{18}$ (ilustr. 8).

Obydwie ilustracje — zarówno ta wyobrażająca Mohorta, jak i ta pokazująca Kościuszkę - przedstawiają rycerzy, którzy — podobnie jak Maria — wyglądają tak, jakby byli pogrążeni w głębokim śnie. Na rycinach nie widać ran, znika podarty, zbryzgany krwią i błotem mundur, twarze bohaterów nie noszą oznak cierpienia. Przywodzą na myśl śpiących rycerzy, spoczywających na barokowych katafalkach, w całym patosie i dostojeństwie śmierci.

Powróćmy do Sienkiewiczowskiej trylogii. Jeszcze innym przykładem sceny ukazującej makabrę śmierci jest kaźń Azji Tuhajbejowicza przedstawiona w Panu Wołodyjowskim $^{19}$. Literacki opis ciągnie się przez kilka stron, zatem powiedzmy jedynie dla przypomnienia: egzekucji dokonuje specjalista od tortur, wachmistrz Luśnia na polecenie Nowowiejskiego, husarza i przyjaciela Wołodyjowskiego. Azja, ocucony z nieprzytomności, spostrzega, że leży na ziemi ze świeżo naostrzonym palem między kolanami; widzi orczyki przywiązane do swoich rąk wyciągniętych ponad głową, u orczyków zaprzężone konie. Zaczynają go nawlekać na pal, wachmistrz każe ruszać końmi wolno, żeby męczarnia trwała długo; kości Azji rozstępują się, ciało zatrzymuje się na drzazgach, na chropowatościach pala i rozdziera się na dwie części. Ostrze pala dochodzi głęboko pod piersi, wtedy dragoni dźwigają pal do góry i wkopują w ziemię; ciało obsuwa się całym ciężarem i dalej rozdziera. Wachmistrz Luśnia każe się podsadzić do Azji i świdrem wywierca mu drugie oko, delikatna skóra owija się wokół skrętów świdra, z oczodołów wypływają strumienie krwi. Tak wygląda zamknięcie tej sceny:

Twarz sama zbielała i stawała się coraz bielsza. Dragoni poczęli gasić w milczeniu pochodnie, jakby wstydząc się, że światło oświeca dzieło tak okropne - i tylko od księżycowego sierpa szły srebrne, lecz niezbyt jasne blaski na ciało Azji. Głowa jego pochyliła się zupełnie na piersi, tylko przywiązane do dębczaka i owinięte smolną słomą ręce sterczały ku górze, jakby ten syn Wschodu wzywał zemsty tureckiego półksiężyca na swych oprawców. Przed samym wsiadaniem wachmistrz zapalił jeszcze ostatnią pochodnią owe wzniesione ręce Tatara, po czym oddział ruszył ku Jampolowi, a wśród gruzów Raszkowa, wśród nocy i pustki został tylko na wysokim palu sam Azja, syn Tuhaj-beja — i świecił długo... ${ }^{20}$.

„W głuchym czarnym stepie świeci ta pochodnia długo — widać ją zapewne na mile dokoła" 21 - dopowiada profesor Stanisław Tarnowski, krytyk literacki, i zadaje sobie pytanie:

\footnotetext{
${ }^{18}$ K. Suffczyński, Zawsze oni. Obrazy historyczne i obyczajowe z czasów Kościuszki i legionów, t. 1, Poznań 1875. Drzeworyt, rys. J. Kossak.

${ }^{19}$ Album Henryka Sienkiewicza „Pan Wotodyjowski”, Warszawa 1900. Cynk, rys. S. Batowski, J. Kossak i W. Tetmajer.

${ }^{20}$ H. Sienkiewicz, Pan Wotodyjowski, Warszawa 1955, s. 576-577.

${ }^{21}$ S. Tarnowski, Z najnowszych powieści polskich. Henryka Sienkiewicza "Potop” — „Pan Wotodyjowski”, „Przegląd Polski”, R. 23, t. 90, Kraków 1888, s. 266.
} 
Co ona oświeca? Czy barbarzyństwo polskie? chyba to jedno, a w takim razie oświeca nieprawdę, oświeca coś, czego nie było. Wiemy, że to czasy tortur i wbijania na pale, ale Nowowiejski, człowiek dobry, Nowowiejski rycerz, Nowowiejski chrześcijanin, mógł zemsty pragnąć, mógł ją wykonać, mógł obiecywać sobie, że się będzie pastwił z rozkoszą, ale gdy istotnie przyszło do rzeczy, nie mógł się pastwić, nie mógł tej długiej męki wytrzymać, nie mógł pozwolić, żeby Luśnia świdrował oko; musiał się przerazić i ulitować razem, i skrócić to straszliwe konanie. Raz nas więc i martwi ta tortura w naszym uczuciu polskim i chrześcijańskim, bo przez nią zbrodniarz wychodzi na męczennika, pokrzywdzony i rycerz — na oprawcę. [...] Nic nie pomoże wyrazistość i plastyczność obrazu; przy takich scenach jak ta staje się ona tylko nadużyciem wyjątkowego epickiego uzdolnienia i daru ${ }^{22}$.

Rzeczywiście, scena ta należy do najmocniejszych literackich zobrazowań wykorzystujących poetykę frenezji okrucieństwa i śmierci w polskiej literaturze. Podobne studia przemocy odnajdujemy dla przykładu u Słowackiego mistycznego, u Goszczyńskiego w Zamku Kaniowskim, następnie u Żeromskiego, a współcześnie u Odojewskiego. W całej historii rodzimej literatury takich scen jest niewiele — tym większe więc budziły zastrzeżenia.

„Pornografia tego cierpienia zawstydza nawet ludzi wojny”23, którzy „poczęli gasić w milczeniu pochodnie, jakby wstydząc się, że światło oświeca dzieło tak okropne"24. Czytając opis Sienkiewicza, przerażającą torturę śledzimy z bliska — wydaje się nawet, że jesteśmy zbyt blisko. Według Tarnowskiego, który potraktował Nowowiejskiego jak wzór realnej postaci, polski rycerz-patriota-chrześcijanin nie mógł być oprawcą, zatem cała scena została po prostu zmyślona. Ponadto przekroczono miarę okropności i obrzydliwości, dopuszczalną dla opisów literackich. Tarnowski, w sposób bezkompromisowy rozprawiając się z tą sceną, nie widzi żadnego usprawiedliwienia dla opisywania tak bezsensownego okrucieństwa. Wstrząśnięty drastycznością sceny literackiej krytyk zarazem jednak ją powtarza. W swym omówieniu zachowuje wszystkie detale, a nawet dodaje własne, jakby opis Sienkiewicza budził fascynację i podziw dla talentu pisarza ${ }^{25}$.

Scena, oburzająca w oczach krytyka — a jednocześnie zapalonego entuzjasty Sienkiewicza - wydała się jednak na tyle ważna, że ujęto ją w albumie do Pana Wołodyjowskiego z roku 1900, przedstawiającym 14 ilustracji z całej powieści. Rysunek wykonał Włodzimierz Tetmajer. Zawiódłby się jednak ten, kto pomyślałby, że zobaczy scenę prawdziwie drastyczną lub chociaż zbliżoną do literackiej prawdy. Ilustracja przedstawia niemal romantyczną scenerię: księżyc, step, odjeżdżające wojsko, w tle wieże cerkwi. Okaleczone ciało, „które wraz z obiektami cywilizacji i kultury materialnej tworzy terytorium, na którym manifestuje się przemoc wojenna" ${ }^{26}$, jest zakryte przez ciemność. Cała makabra, która ciagnie się przez kilka stron powieściowego opisu, na rysunku już się dokonała. Widzimy odjeżdżających rycerzy i choć doskonale wiemy, co miało miejsce jeszcze przed chwilą, ilustracja staje się dla tej wiedzy poniekąd „zasłoną”. Wydaje się, że nie podejmuje dialogu z literackim pierwowzorem — artysta nie

\footnotetext{
${ }^{22}$ Tamże, s. 266-268.

${ }^{23}$ R. Koziołek, Ciała Sienkiewicza, Katowice 2009, s. 292.

${ }^{24}$ H. Sienkiewicz, Pan Wołodyjowski, s. 576.

${ }^{25}$ Zob. R. Koziołek, dz. cyt., s. 292.

${ }^{26}$ Tamże, s. 260.
} 
„wypowiada” tu swoich poglądów na temat przemocy wojennej, bo „wejście w dialog oznacza otwartość na trudne sprawy, na świat, na człowieka, na wartości - wszel$\mathrm{kie}^{27}$, a na to nie pozwalała konwencja ilustracyjnego przedstawienia.

Dokonując operacji na czasie i wybierając właśnie ten moment do zilustrowania, grafik zdystansował się od samej sceny kaźni. Literacki opis przełożony na obraz został wyczyszczony z werystycznej dosłowności. Nie widać podpalonych dłoni, które upodabniały Azję do pochodni płonącej samotnie w stepie. Na pierwszy rzut oka wbity na pal syn Tuchajbeja może przypominać przydrożną kapliczkę, co — zgodnie z zarzutem Tarnowskiego wobec sceny literackiej — narzuca symbolikę ofiary. Ilustracja nie pokazuje zatem okrucieństwa tekstu, a estetyzacja plastycznego wyobrażenia staje się formą protestu przeciwko makabrze, protestu ideologicznego i etycznego. Mamy tu więc do czynienia z sytuacją odwrotną od tej, o które pisze Karol Głombiowski: „A przecież w procesie przekazu dzieła literackiego chodzi o to, aby artysta-grafik dopowiedział ołówkiem lub rylcem to, czego poeta nie chciał albo nie mógł słowem wyrazić" ${ }^{28}$. Pragnienie dopowiedzenia nie oznacza tu głębokiego zanurzenia w literacki opis i wizualizowania go, uzupełniania o szczegóły. Ilustracja Włodzimierza Tetmajera, poprzez określoną perspektywę przedstawienia, podjęcie plastycznej opowieści w tym momencie, kiedy wszystko już się dokonało, nie podąża za Sienkiewiczowskim studium torturowania ciała. Nie eksponuje cielesności człowieka, doświadczenia bólu ani barbarzyństwa tej zemsty. Tłumi okropność opisu literackiego i broni się przed jego przemocą - a zarazem perwersyjną sugestywnością. Wreszcie pogrąża literacką scenę w kategorii niepokazywalnego. Zasadne wydaje się pytanie o to, co pozostało w pamięci czytelników, którzy jednocześnie byli odbiorcami albumu — tekst książki, w którym wszystko jest opisane z przeraźliwą jasnością, czy ilustracja, w której milknie narracja Sienkiewicza (ilustr 9).

Ostatnią sceną, o której chciałabym napisać, jest ukazana przez Kraszewskiego w Starej baśni kaźń Henga, z wyrafinowanym okrucieństwem zamęczonego przez Dobka. Ilustrację do tekstu wykonał Michał Elwiro Andriolli. Scena ta jest ważna między innymi dlatego, że ukazuje przemyślane okrucieństwo bohatera, który w świecie przedstawionym powieści należy do postaci pozytywnych, choć niejednoznacznych. $\mathrm{Z}$ urodzenia kmieć, z zamiłowania wojownik, w polu i na łowach „szalony i niespracowany, gdy do domu przybył, zwykł był przy ogniu legować albo pod drzewem na murawie" 29 . Dobek zarządza znacznymi obszarami ziemi, lubi używać życia, choć gdy wyrusza na polowanie, wodzi swych ludzi po lasach o głodzie i chłodzie, krzepiąc się wodą z kałuży. Jego gwałtowny i dziwaczny charakter przejawia się również w podejściu do przyjaciól, za których potrafi nadstawić karku, jednak „gdy najmniejsza waśń poróżniła go z bratem, ubić był gotów na razie... i potem żałować" ${ }^{30}$. Jedną z cech

\footnotetext{
${ }^{27}$ A. Pilch, $d z . c y t$., s. 80.

${ }^{28}$ K. Głombiowski, dz. cyt., s. 59.

${ }^{29}$ J. I. Kraszewski, Stara baśń. Powieść z IX wieku, Warszawa 1960, s. 374.

${ }^{30}$ Tamże, s. 374.
} 
wyróżniających Dobka jest jego przebiegłość, która sprawiała, że „zataić się umiał do czasu, z człowieka wyciągną́c, a samemu się przyczaić cicho. $Z$ tej strony mało go kto znał oprócz własnych ludzi” ${ }^{31}$. Choć w środku kipi z emocji, potrafi słuchać cierpliwie. Z takim właśnie przeciwnikiem, niczego nieświadomy, podróżuje Hengo — zdrajca słowiańskiego plemienia, szpiegujący pod pretekstem handlu. Pragnący się zemścić Dobek, obdarzony olbrzymią posturą, w jednej chwili mógłby przebić mieczem swojego towarzysza, ale — jak pisze Kraszewski — „rozbolałemu człowiekowi tej zemsty było za mało"32. Gdy podróżnicy stają na popas i rozpalają wielkie ognisko pod dębem, Dobek prosi Henga, by ten pomógł mu skręcić sznur. Nieświadomy niczego Hengo ochoczo pomaga, co wykorzystuje Dobek, by skrępować przeciwnika. Następnie zawiesza Niemca nad ogniem, by ten upiekł się żywcem, „a sam nieco opodal spokojnie się położył na trawie, ogień tylko podkładając" ${ }^{33}$. Dobek nasyca się cierpieniami wroga, podczas gdy Hengo błaga o łaskę szybkiej śmierci. Dobek pozostaje na to obojętny, póki nie znudzi mu się trwające tak długo konanie przeciwnika. W milczeniu podsyca ogień, tak żeby płomienie ogarnęły Henga, i żeby ten czym prędzej umarł w męczarniach. Ostatecznie, jak czytamy w tekście:

Oczekiwanie znużyło znać Dobka, bo chwyciwszy oszczep, rzucił nim w piersi i dobił nieszczęśliwego. Odszedł potem od ogniska, a wkrótce ciało urwane z gałęzią padło w ogień, żar i iskry rozpryskując dokoła, objęły je płomienie. Najmniejszej już wątpliwości nie było, iż Hengo odżyć nie może, skoczył więc Dobek na koń splunąwszy na trupa i szybko się oddalił. Lżej mu się potem zrobiło $[\ldots]^{34}$.

Jeśli wziąć pod uwagę zarówno mit łagodnego Słowianina, jak i tendencję do idealizowania postaci zasłużonych w walce z najeźdźcą, opisana scena budzi zastanowienie. Jest to bowiem akt celebrowania długiej, bolesnej śmierci. Chęć zemsty, której nie kojarzymy z pokojową słowiańską duszą i kulturą, tak jak chciał ją widzieć Herder, prowokuje sadystyczne zachowania, potrzebę delektowania się powolnym zadawaniem śmierci swoim wrogom. W tym sensie Dobek nie walczy jak rycerz, a mimo fizycznej przewagi, umożliwiającej mu zadanie Hengowi śmierci w mgnieniu oka, decyduje się na straszną egzekucję. Andriolli doskonale uchwycił w ilustracji tę różnicę w fizyczności obu bohaterów, przedstawiając Dobka jako rosłego mężczyznę w odróżnieniu od wijącego się w agonalnych ruchach Henga. Andriolli, jakby chciał w sposób szczególny podkreślić tę dysproporcję, przedstawił Dobka jako mężczyznę drobnej budowy, co nie rzuca się w oczy na innych ilustracjach wyobrażających tego bohatera. Dodajmy, że w tej scenie — w odróżnieniu od wcześniej opisanych przedstawień śmierci — grafik nie cofa się przed ukazaniem fizycznego wymiaru cierpienia. Postać Henga jest skręcona spazmatycznie, jego twarz wyraża cierpienie, ból i przerażenie. Jednak takie graficzne ujęcie należy do rzadkości (ilustr. 10).

\footnotetext{
31 Tamże, s. 374.

32 Tamże, s. 381.

33 Tamże, s. 382.

${ }^{34}$ Tamże, s. 382.
} 
Obrazy śmierci wzniosłej, tak jak w przypadku pięknej Marii czy Longinusa Podbipięty, potwierdzały wyobrażenia kulturowe, gloryfikujące polskość. Ilustrujące te sceny rysunki jako forma reprezentacji stały się rodzajem przedstawienia, dzięki któremu polskie społeczeństwo w drugiej połowie XIX wieku utwierdzało się w takim obrazie świata, jaki mógł być przez nie uznany za własny i sensowny, odwołując się do sformułowania Michała Markowskiego. Obrazy makabry, okrucieństwa, zdziczenia polskich rycerzy wykraczały natomiast poza ten porządek wyobrażeń, poza horyzont oczekiwań czytelników, które wyznaczały „w ówczesnej Polsce większość działań artystycznych i współtworzyły swoistą "chorobę polonizmu " panującą w sztuce przez całą omawianą epokę"35 - jak zauważa Waldemar Okoń. Makabra śmierci przejawia się tu w bestialstwie wojny i zdziczeniu. To ostatnie dotykało walczących po obu stronach, co wyraźnie podkreśla Sienkiewicz w Trylogii, opisując wojnę jako pogrom totalny, rzeź, w której „nie żywiono nikogo”, „rzeczywistą potworność wojny z jej bezwzględnym, niszczącym same podstawy bytu okrucieństwem" ${ }^{36}$. Drastyczność tekstu w interpretacji ilustratorów, poddanych akademickim rygorom, była natomiast znacznie łagodzona. Przedstawione wizualizacje kaźni Azji oraz Dobka noszą znamiona zemsty sprawiedliwej, w której okrucieństwo stanowi odpłacenie za nieusprawiedliwione zbrodnie. Powstaje pytanie, czy Sienkiewicz, jak również Słowacki mistyczny czy Seweryn Goszczyński przedstawiający sceny rzezi humańskiej i Ukrainy targanej koliszczyzną oraz innymi tragicznymi powstaniami, mogli upleść heroiczną historię z okrutnych dziejów. Mogliby ukazać te czasy w patetycznej wzniosłości, jednak było to zadanie niemożliwe. Zarazem ich dzieła, przybliżające okropności oczom odbiorców, wywoływały gwałtowne protesty i krytykę czytelników. Jednak tu otwiera się przed nami już zupełnie inny problem badawczy.

Dąbrówka Mirońska

\title{
Literary and Graphic Visions of Death in $19^{\text {TH }}$-Century Illustrated Editions of the Polish Fictional Literature
}

\begin{abstract}
Summary
The article is particularly concerned with the visions of death in $19^{\text {th }}$-century illustrated editions of the Polish fictional literature. The choice of conducting such research resulted from my interest in book as an item which is produced as the effect of cooperation of many people: author, illustrator, editor and printer. I treat the book as a whole, in which coexist both: the text and its graphic visualization.

The investigation into the relations between iconic signs, on the one hand, and literary narration on the other, emphasized the necessity of taking into account the relevant aspects of illustration as a specific way of communicating. The problems included, inter alia: how visual arts interpret the description of literary scenes and characters; in what way illustration explains, supplements as well as modifies the text and intensifies its effects; why some literary scenes deserved to be graphically emphasized and the other ones did not; finally why the situation of illustration perversely "decoding" a message given by text occurred. The "points of junction" of the literary and icon elements, the meaningful role of the latter, the reinterpretation of one work by another were also treated as the vital problems.
\end{abstract}

${ }^{35}$ W. Okoń, Sztuki siostrzane..., s. 10.

${ }^{36}$ M. Janion, Ptacz generata. Eseje o wojnie, Warszawa 1998, s. 37. 
The article consists of five parts which exemplify the main problem on selected examples. The first part deals with general questions relating to the role of illustrations in $19^{\text {th }}$ century. The second part is devoted specifically to the scene of death of main heroine in Maria, the $19^{\text {th }}$-century a poem by A. Malczewski, the most popular literary work among Polish artist at that time. The third part is concerned with three examples of ars bene moriendi in Polish literature (H. Sienkiewicz Ogniem i mieczem, W. Pol Mohort and K. Suffczyński Zawsze oni). The last to be discussed in the fourth part are the scenes of cruel deaths (H. Sienkiewicz Pan Wotodyjowski, J. I. Kraszewski Stara baśń). The last part focuses on the final conclusions.

My research provided me with useful insights into the problem. The comparison between literary narration with the way of the telling the same story by means of pictures unveiled the fact, that the illustrations established and codified ideological visions of the Polish history for many years. They were a critical instrument of building cultural code as well as national identity in the period of the partitions of Poland. On the other hand, the conclusion deals with the problem of the text being "betrayed" by the illustration as the visual representation modified the elements of the literary message. This situation occurred very often in $19^{\text {th }}$ century against common conviction of critics and researchers. 